\title{
Accounting
}

\section{CEO inside debt compensation determinants and bank performance: Empirical evidence from Europe}

\section{Bassam Al-Own ${ }^{\text {a* }}$}

${ }^{a}$ Faculty of Economics and Administrative Sciences, Department of Finance, Al al-Bayt University, Mafraq 025110, Jordan

\section{H R O N I C L E}

\section{Article history:}

Received May 152020

Received in revised format May

162020

Accepted July 62020

Available online

July 62020

\section{Keywords:}

Inside debt compensation

Debt-based compensation

Bank performance

European banks

\section{A B S T R A C T}

The main purpose of this paper is to examine the effect of inside debt compensation on bank performance, and identify the determinants of inside debt compensation. Using a sample of thirty European Banks during the period of 2006-2011, this paper presents evidence to support the existing literature that states that debt-based compensations plans have a significant impact on banks' performance. The results imply that banks rely more on a debt-based compensation as leverage increases. A positive association has also been documented between debt-based compensation usage and both CEO age and bank size. The human capital of CEOs has been found to be negatively related to debt-based compensation. The empirical findings show that there is a significant negative relationship between inside debt compensation and banks' performance. Specifically, CEOs paid with a higher level of inside debt compensation were more likely to engage in lower risk-seeking behavior, such as adopting more conservative policies and investment choices. Thus, inside debt compensation plans can influence the risk-taking of managers, which may have the potential to significantly affect bank performance. Generally, inside debt compensation can reduce risk-shifting problems and lead to behavior which positively impacts debt-holders, as less risk-taking can directly contribute to a lower probability of default. The findings of this paper present important implications for many interested parties throughout the European Union, such as regulators, investors, and standards setters, whose aim is to enhance the soundness of the banking sector.

\section{Introduction}

This paper examines the association between debt-based compensation plans and performance in the banking sector. The last financial crisis, which began in late 2007, led to an increasing and growing concern about the effect of executives' compensation on the value and risk of financial firms (Bai \& Elyasiani, 2013). A great amount of prior research has investigated how executive compensation plans affect firms' risk-taking and performance (Buck et al., 2003; Guo et al., 2006; Fahlenbrach \& Stulz, 2011; Tung and Wang, 2011). These research studies discuss the relationship between performance and different forms of compensation, such as equity-based compensation (stock and stock-options), salaries, and cash bonuses compensation plan (e.g., Mehran, 1995; Core \& Guay, 1999; Frye, 2004; Guo et al., 2006). However, defined benefits plans, which are considered a primary component of executives' compensation contracts, represent an important type of "inside debt" compensation, are widely used, and often represent a substantial form of CEO compensation package has received less attention from academics (Cadman \& Vincent, 2014; Choy et al., 2014; Wu \& Lin, 2019). For example, it has been reported that more than 50\% of CEOs

* Corresponding author. Tel.: +962778352027

E-mail address: Bown@aabu.edu.jo (B. Al-Own) 
of S\&P500 firms receive substantial defined benefit pensions as a fraction of their total incentive compensation (Sundaram and Yermack, 2007). In the European banking industry, statistics show that around half of the banks listed publicly in the market index of the EU27 provide pension compensation to their executives. Executives may prefer inside debt compensation because this type of compensation is generally not taxable to the recipient until it is received; as such, this form of executive compensation does not lead to an increase in current taxes. Defined benefit plans also provide additional rewards while saving the firm current capital (compared to cash bonuses) and avoiding earnings dilution (compared to equity compensation). However, CEO inside debt compensation plans expose CEOs to a firm's bankruptcy risk, and its potential failure to fulfil pension obligations (Cadmana \& Vincent, 2014). CEO compensation contracts are designed to provide an incentive to increase both corporate value and shareholders' wealth. However, executives' compensation contracts may consist of elements which divert wealth to shareholders at the expense of debt-holders, such as equity-based compensation. The incentives streaming from equitybased compensation can result in risk-shifting that benefits equity-holders but does not protect debt-holders' interests (Sundaram \& Yermack, 2007; Edmans \& Liu, 2011). This shows that executives' compensation packages can be formulated as a convex function of firm value. A convex compensation contract will make managers' utility less concave in relation to firm value, and executives could be encouraged to implement more risky policies (Jensen \& Meckling, 1976; Srivastav et al., 2014). Unlike other elements of CEO compensation packages, the incentives associated with debt-based compensation can result in more conservative behaviour, which can reduce a firm's risk. This type of compensation plan can make executives' utility more concave to a firm's value, and provide incentives to pursue less risky policies. Inside debt compensation, such as defined benefit pension plans, can play an important role in addressing risk-shifting problems by aligning the interests of executives with those of debt-holders, regulators, and taxpayers (Srivastav et al., 2014). This implies that the responses of executives to debt compensation can affect the performance of a firm.

The executive incentive to increase firm value is normally measured as the sensitivity of executive wealth to a firm's annual performance (Jensen and Murphy, 1990). This paper explores the effects of defined benefit pension plans on firm performance, as prior empirical studies have generally not included the value of defined benefits plans as part of the compensation measures which can affect performance (e.g. Guo et al., 2006). In 2003, the European Union Commission recommended that all European member countries are required to encourage firms to disclose individual executives' compensation (Cadmana \& Vincent, 2014). The increase in the required disclosure of information about executives' inside debt compensation provides an opportunity to examine the role and implications of debt-like compensation compared with previous studies (Bebchuk \& Jackson, 2005; Gerakos, 2008). This paper aims to fill this gap by analysing the impact of CEOs' defined benefit plans on bank performance and its determinants. The importance of this form of executive compensation in mitigating risk shifting behaviour has been underestimated, and the association between debt-based compensation and performance generally overlooked.

This paper is organized as follows. Section 2 provides literature review. Section 3 and 4 present hypotheses development, data and methodology. The empirical results are presented in Section 5. Finally, conclusions are presented in Section 6.

\section{Literature review}

The role of inside debt compensation as a form of compensation and an instrument of achieving personnel objectives has received greater attention from researchers in the last decade. Specifically, after the last financial crisis and after the widespread use of debt-based compensation which implies that providing inside debt compensation to executives will not adversely affect the performance or the profitability of firms.

Several studies on executives' pay have examined executive incentives by excluding the value of debt-based compensation or pension plans (Acrey, McCumber, and Nguyen, 2011; Fahlenbrach and Stulz , 2011; Hagendorff and Vallascas, 2011). This stream of studies has a central role in building a deep understanding of the impact of equity-based compensation on the alignment between executives and the interests of shareholders; however, the alignment between executives and debt-holders interests has received less attention by prior empirical studies (Cassell et al., 2012).

Allen and Clark (1987) presented pioneering empirical evidence that the performance of a firm in not affected by pension compensation. Their results show no significant correlation between a firm's productivity and pension compensation. They explain that firms use pension compensation as a method to reduce employee turnover, which means using less resources to hire new employees. Edmans (2006) later introduced a model which suggests that using debt-based compensation in executives' contracts can mitigate the risk shifting problem, which occurs when shareholders substitute riskier assets for the firm's assets.

Many studies have examined the link between inside debt compensation and default risk in the banking industry. Using a sample of 371 bank holding companies, Bennett et al. (2012) examined how the structure of a CEO's compensation contract can explain default risk and performance during the credit crisis which began in 2007. They find that, in 2006, a higher holding of debt compensation relative to equity compensation by a CEO was correlated with lower default risk and better performance during the crisis period. The evidence shows that, before the onset of the crisis, banks with higher debt compensation ratios also had higher ratings, indicating stronger capital positions, better management, higher earnings, and being in a better position to withstand market shocks in the future. Bekkum (2016) finds that the inside debt compensation of top officials in U.S. banks is 
negatively related to risk measures. The results also indicate that large inside debt compensation leads to better balance sheet management, and encourages managers to adopt more conservative decision making.

More recently, Ma et al. (2020) show that greater use of debt compensation in the banking industry is extremely helpful in reducing a bank's risk of default. Milidonis et al. (2019) find that the incentive effect of CEO debt compensation on the insurance companies is negatively associated with risk-taking behaviour. Sheikh (2019) indicates that CEO inside debt compensation can be used to encourage managers to manage corporate risk-taking, documenting an inverse relationship between inside debt compensation and future risk. Nevertheless, Srivastav et al. (2014) mention that the topic of inside debt compensation "is still a 'black box' wherein the mechanisms through which inside debt decreases bank risk remain largely unidentified and warrant further attention".

Liu et al. (2014) find evidence that inside debt compensation can harm stockholders' value, showing that the marginal value of cash to shareholders decreases as executive debt compensation increases. Cassell et al. (2012) note a negative relationship between inside debt holding and a firm's stock returns in a sample of financial and non-financial firms. They suggest that firms with more debt compensation tend to prefer less risky investments and financial policies.

In general, many prior studies suggest that the use of inside debt compensation plans clearly aligns the incentives of management with those of creditors, and mitigates their incentives to transfer wealth from debt-holders to shareholders (Anantharaman et al.,2014; Galdeano et al., 2019; Edmans and Liu, 2011; Sundaram and Yermack,2007; Choy et al., 2014; Gerakos, 2010). Sundaram and Yermack (2007) use a sample of 237 firms between 1996 and 2002 and document that executive defined benefit pension plans align the executives' interests with those of debt-holders. They note that inside debt compensation plays an influential role in reducing the CEO's risk taking because the promised pension benefits represent the firm's inside debt.

Moreover, debt-based compensation plans may encourage managers to stay with a firm, as the opportunity cost in lost benefits is increased if they leave the firm early, and this also gives firms the chance to control retirement by accelerating benefits to encourage retirement when desired (Lazear, 1979, 1983). Srivastav, Armitage, and Hagendorff (2014) use a sample of 103 U.S commercial banks between 2007 and 2011 to assess how inside debt compensation affects risk-shifting behaviour. They conclude that CEOs' defined benefit pension plans provide incentives to protect debt-holders' interests, as this type of compensation is associated with more conservative policies and reduces risk-shifting behaviour.

\section{Hypothesis development}

According to agency theory, executive compensation contracts are one of the most important influential factors on a firm's performance. Top executives are considered in the literature to be risk-averse, which implies that those executives will prefer a compensation structure which involves less personal risk, because the value of their human capital will be affected by firms' stock performance. Executives will thus have an incentive to reduce the firm's risk in order to reduce their own compensation risk. This incentive can in turn negatively affect the wealth of shareholders, who are considered risk-neutral as they have the ability to reduce a firm's specific risk by holding a diversified portfolio (Jensen \& Meckling, 1976). The insight of Jensen and Meckling's (1976) study provides an opportunity to explore the effect of inside debt compensation on bank performance. The authors hypothesise that there is an optimal ratio of a CEO's inside debt-to-equity. This optimal ratio can ensure that a manager's interests are equally aligned with those of equity-holders and debt-holders, and mitigate the incentives to shift risk to debtholders.

Defined benefit represents one of the main forms of inside debt compensation, and constitutes an important portion of both annual compensation and firm-related wealth for many CEOs (Cadman \& Vincent, 2014). The payoff of this type of compensation is made up of unsecured liabilities of a firm, and depends on the incidence of default and the liquidation value of the firm (Edmans and Liu, 2011; Srivastav et al., 2014). Managers compensated with debt-based compensation face a trade-off between their debt-based wealth and maximising the value of their firm based on the firm's performance. However, inside debt compensation exposes executives to the risk of the firm's bankruptcy, as if they were holding a piece of the firm's risk debt (Liu et al., 2014).

The risk aversion hypothesis suggests that managers who are granted debt-like compensation tend to prefer making less risky investments, as this compensation can be viewed as unsecured corporate debt. Therefore, inside debt compensation can be seen as an instrument which offsets the incentives of equity-based compensation, and motivates managers to make choices that benefit debt-holders at the expense of shareholders (Tung \& Wang, 2012; Liu et al., 2014).

Traditionally, debt-like compensation has been used by firms to reward top executives and align their interests with those of debt-holders. This implies that aligning the interests of debt-holders and executives may affect a firm's performance. This paper investigates whether bank performance is negatively related to the use of debt compensation granted to executives. Using a sample of CEOs from large European listed banks, this study investigates whether inside debt compensation was associated with a significant influence on bank performance during the period of 2006 to 2011 . The reason that this paper focuses on banks is that banks are mainly funded by depositors and debt-holders and much less by stockholders, making the debt agency problem 
particularly severe in the banking sector (Bekkum, 2016). This paper hypothesises that CEOs of banks who are paid with debtlike compensation will be more likely to adopt more conservative policies which negatively affect bank performance. Thus, and based on the above discussion, the hypotheses are as follows:

\section{H1: Inside debt compensation is positively associated with the leverage of a firm.}

The agency problem may be less important in highly leveraged firms, as debt-holders could play an effective role in increasing the use of inside debt compensation rewards (Guo and Yang, 2006). Core and Guay (2001) suggest that a firm's ability to borrow money can affect the compensation granted to its CEO. Firm's leverage may be proxy for the ability to borrow money. Prior empirical studies suggest that leverage appears to be an important determinate of executive compensation. Liu et al. (2014) show that, as leverage increases, CEOs with debt compensation increase the cash balance to hedge the risk of financial distress. Thus, a positive association is expected between leverage and debt compensation.

H2: Inside debt compensation is positively associated with the size of a firm.

According to agency theory, executives in large firms are more difficult for shareholders and debt-holders to monitor. Hence, firm size may affect the use of executive compensation in general, and performance based remuneration specifically. Firm size is commonly used as a variable in executive compensation literature in modelling the CEO's incentives (e.g. Guay, 1999; Rogers, 2002; Coles et al., 2006; Frye, 2004). Cadman and Vincent (2014) suggest a positive correlation between firm size and all elements of pay. Therefore, inside debt compensation is expected to be related to firm size. This implication suggests a positive association between firm size and the use of inside debt compensation.

H3: Inside debt compensation is positively associated with the growth potential of a firm.

Empirical literature discusses a positive relationship between a firm's growth opportunities and the awarding of inside debt compensation to top executives (Cadmana \& Vincent, 2014). The asymmetry information between executives and owner of the firm can be significant in firms with more growth opportunities (Guo \& Yang, 2006). Thus, it is expected that firms with greater opportunities for growth will be more likely to provide their executives with a higher level of inside debt compensation.

H4: Inside debt compensation is positively associated with the age of a CEO.

Certain personal characteristics of CEOs may also be associated with inside debt compensation. Bennett et al. (2012) suggest a positive association between CEO age and risk-taking. Cadmana and Vincent (2014) also posit that older CEOs are more likely to prefer debt compensation. Thus, older executives are expected to be more risk-averse and have a greater preference for inside debt compensation.

H5: Inside debt compensation is positively associated with the length of a CEO's tenure.

CEOs with longer tenures are more likely to prefer inside debt compensation plans as they approach retirement. Prior literature suggests a positive association between CEO tenure and the use of forms of deferred compensation (Sundaram \& Yermack, 2007; Cen, 2010). Nevertheless, other empirical studies provide evidence of a negative association between CEO tenure and the presence of inside debt compensation (Cadmana \& Vincent, 2014; Liu et al., 2014; Dang, 2019).

H6: Inside debt compensation is negatively associated with a CEO's human capital.

CEO human capital is represented by the CEO's cash compensation. Prior empirical evidence suggests that the debt-holders of a firm are more concerned about executive opportunism when the CEO is compensated with less cash compensation. Rogers (2002) suggests that CEOs with higher levels of cash compensation are more likely to be paid in the form of equity-based compensation, such as stock options, as the value of option grants is not deducted for tax purposes. Based on previous studies, CEO salary and cash bonuses are used as a proxy of human capital, which is expected to be negatively associated with inside debt compensation (Core et al., 1999; Begley \& Feltham, 1999).

H7: Inside debt compensation is negatively associated with firm performance.

Previous research concerning executives' compensation suggests that this form of CEO compensation plays an evident role in aligning the interests of executives and outside debt-holders. Accordingly, CEOs may prefer less risky policies, which will lead to more conservative choices, and therefore affect a firm's performance (Bekkum, 2016; Edmans \& Liu, 2011).

This paper sheds light on the debate about the role of inside debt compensation by establishing a direct link between CEO incentives from defined benefit compensation and bank performance in the European banking sector. Analysing the effects of CEO compensation, including inside debt plans, can provide a more complete picture of the incentives arising from executives' compensation plans. 


\section{Data and methodology}

This paper extends prior empirical literature and examines the determinants of inside debt compensation and whether this type of executives' compensation affects performance in the banking industry. The banking sector has a great impact on the stability of the financial system, and the compensation of CEOs in this sector has been subject to great criticism both during and following the last financial crisis (Claessens \& Horen, 2015; Cheng et al., 2011).

This shows the significance of studying the association between debt-based compensation and performance in banking industry. This section discusses sample selection criteria, data sources, variables measurements, and models.

\section{Sample}

The sample used to interpret the linkage between inside debt compensation and banks' performance and the determinants of inside debt compensation is extracted from publicly-listed European banks. Banks had to meet the following criteria in order to be included in the sample: Firstly, the bank should be based in Europe, and operate within the European banking sector. Secondly, the bank should be included in European stock market indices and premier indices of the European Union countries (EU-27) during the period of investigation. Thirdly, the bank should have available data with which to test the relationship between the variables of the study. The final sample consists of 30 banks, and covers the time period of 2006 to 2011.

The sample period begins in 2006 for three main reasons. Firstly, before 2006, research on CEOs' inside debt compensation was constrained by the availability of reported data. However, a comprehensive disclosure reform in 2006 greatly improved the transparency of CEOs' debt compensation, and this regulatory change enhanced the information reported by publicly-listed firms and provided more adequate data for analysis (Wei \& Yermack, 2011 Liu et al., 2014; Srivastav et al., 2014) ${ }^{1}$. Prior to 2006, firms were not required to disclose details about executives' deferred compensation plans, and thus, the deferred compensation balances held by executives were not observable (Cen, 2011; Liu et al., 2014; Bolton et al., 2015). Bebchuk and Jackson (2005) predict that the new disclosure requirements will reveal considerable amounts of performance-insensitive compensation in executives' pensions.

European countries have adopted more extensive CEO remuneration disclosure requirements to provide more information to both investors and policymakers (Murphy, 2012). The UK, for example, has been found to follow stricter disclosure rules for CEO compensation packages (Cadman and Vincent, 2014).

The sample banks used in this paper are both large and well known. Wei and Yermack (2011) show that inside debt compensation plans are much more common in larger companies than smaller ones, and all of the banks included in the sample are index firms. Data on inside debt compensation is hand-collected using the annual reports of publicly listed banks; these annual reports contain adequate information and provide detailed disclosure of defined benefit schemes. Defined benefit schemes, as a form of inside debt compensation, dominate pension compensation in Europe according to European Insurance and Occupational Pensions Authority (EIOPA) stability report 2013.

\section{Compensation data}

CEO compensation data is obtained from annual reports published by publicly-listed banks. The total number of stock options granted, total number of restricted shares granted, and CEOs' monetary compensation (salary and cash bonuses) are also collected. Inside debt compensation for executives can generally be divided into two categories: defined benefit pensions and deferred compensation (Sundaram and Yermack, 2007; Wu and Lin, 2019). In this research study, defined benefit compensation is used as a proxy for inside debt compensation. The value of the stock option grants and the value of restricted shares are added up, following which the value of defined benefit compensation is divided by the total value of equity-based compensation. Following prior literature in director remuneration, Black-Scholes option pricing model is used to calculate the value of stockoptions $^{2}$. The value of restricted stock grant is calculated by multiplying the number of restricted shares granted by the stock price at the relevant date (e.g. Wei \& Yarmck, 2011; Coles et al. 2006; Frye, 2004; Conyon \& Murphy, 2000).

\section{Performance and other bank data}

Following prior literature, return on assets (ROA) and return on equity (ROE) are used as variables to measure bank performance (Kato and Kubo, 2006; Cao et al., 2011; Akram et al., 2015). ROA is a measure of performance that relates a bank's net income to the total assets at the end of the year. Moreover, ROA is an important ratio for comparing the efficiency and performance of banks. This ratio informs stakeholders about the ability of the bank to generate income using bank assets, and is considered a

\footnotetext{
${ }^{1}$ The Securities and Exchange Commission (SEC) requires firms to disclose more details about executive compensation, including valuations of executives' pension benefits and debt-like compensation.

${ }^{2}$ Black-Scholes (1973) option valuation model allows for continuous dividend payments. Variables needed to estimate the value of stock option such as the total number of options at the end of the year; the exercise price, time to maturity and price of underlying stock are collected from banks' annual reports. The Black-Scholes model is commonly used by literature and considered as a better method to estimate the value of executive options (Matsunaga, 1995; Mehran, 1995; Frye, 2004; Alhadab and Alown, 2019).
} 
benchmark by which to compare the bank's performance with that of other banks (Wen, 2010). ROE is another annual financial ratio, which measures performance by showing how much profit a bank earns compared to the total amount of stockholders equity. This ratio shows what shareholders require in return for their investment in the bank. Therefore, a high ROA and ROE ratio indicates better firm performance, and both are important and widely-accepted measures of corporate performance (Ongore and Kusa, 2013). However, care should be taken when weighting ROE ratio too heavily in an analysis, as it may be disproportionately high at the expense of an over-leveraged balance sheet (Cardone-Riportella et al., 2010).

\section{Control variables}

The selection of the control variables used to empirically investigate the possible association between the dependent and independent variable was based on previous empirical literature. Datastream was used to collect data on banks' characteristics and control variables. Much prior empirical literature includes market-to-book ratio, leverage, size, firm risk, CEO age, and CEO tenure as control variables. The proxy of growth opportunities is estimated using the market-to-book ratio. The ratio of book value of debt to total assets is used to estimate banks' leverage. Size is measured as the logarithm of total assets. CEO age and CEO tenure are also included as control variables. Similarly to previous studies, variables are transformed to the natural logarithm where appropriate (Rogers, 2002; Chen et al., 2006; Bai and Elyasiani, 2013).

\section{Models}

Prior literature on CEO compensation proposes the use of ordinary least squares (OLS) and fixed- effects regressions (Gao, 2010).Following prior research (e.g. Cen, 2011; Edmans and Liu, 2011; Tung and Wang, 2011), this paper estimates the following equations using ordinary least squares (OLS) and a fixed effects model. To test the hypotheses about the determinants of inside debt compensation, the following model is used:

$$
\begin{aligned}
& \text { CEO } \text { inside-debt }_{i, t}=\beta 0+\beta 1 . \text { Leverage }_{i, t}+\beta 2 . \text { Age }_{, t}+\beta 3 . \text { Tenure }_{, t}+\beta 4 . \text { Growth }_{\text {opportunities }, t}+\beta 5 \text { Salary }_{i, t}+ \\
& \beta 6 . \text { bonus }_{i, t}+\beta \text { Size }_{i, t}+\mu_{t}+\dot{\varepsilon}_{i, t}
\end{aligned}
$$

Based on previous studies (Jensen and Meckling, 1976; Edmans and Liu, 2011; Tung and Wang, 2011; Srivastav et al., 2014), two main proxies are used for inside debt compensation: first, CEOs' personal inside debt-to-equity ratio (CEO-debt-to-equity). This ratio represents CEOs' defined benefit as a percentage of their equity compensation. Srivastav et al. (2014) point out that this measure captures the relative fraction of a CEO's inside debt and equity-based wealth.The second proxy for inside debt compensation is CEO debt-based compensation to equity-based compensation, divided by bank debt-to-equity ratio or the bank CEOs' relative incentive ratio (CEO-bankdebt-to-equity). Existing literature on executives' compensation suggests measuring executive incentives linked to inside debt via the executive's debt-like relative to equity-like compensation scaled by the firm's debt-to-equity ratio. Research on CEO compensation has shown that leverage and growth opportunities can be important determinants of the type of CEO compensation plan (e.g. Jagtiani et al., 2002; Srivastave et al., 2014). Prior studies have found firm leverage and growth opportunities to be positively associated with debt compensation (Begley, 1994; Sundaram and Yermack, 2007; Cadmana and Vincent, 2014). Large executive cash compensation is considered to align the CEO's interests with those of debt-holders. The results of established studies indicate that cash compensation is negatively associated with the usage of debt compensation (Begley and Feltham, 1999). To examine the effect of inside debt compensation on bank performance, two measures are used as a proxy for bank performance: ROA and ROE. Inside debt compensation is also measured as (CEO-debt-to-equity) and (CEO-bankdebt-to-equity). Accordingly, the second model specification is as follows:

$$
\text { Bank performance }_{i, t}=\beta 0+\beta 1 \text {.inside debt } \text { compensation }_{i, t}+\text { Controls }+\mu_{t}+\dot{\varepsilon}_{i, t}
$$

Inside debt compensation is considered an unsecured firm obligation; this type of compensation is sensitive to firm bankruptcy (Edmans and Liu, 2011). Therefore, CEOs with large debt compensation are expected to decrease firm risk and make less risky investment choices, in order to protect the value of their debt compensation (Sundaram and Yermack, 2007). In other words, CEOs are expected to attempt to reduce the volatility of future firm performance, and are thus more likely to prefer financial policies and investment projects that are less risky, which can negatively affect a firm's performance. The natural logarithm of these measures is used to mitigate the concern that skewness in the distribution of these measures may affect the inferences (Cassell et al., 2012).

\section{Empirical results}

This section first reports the regression results that investigate the determinants of CEOs' inside debt. The regression results concerning the effects of inside debt compensation on bank performance are then reported. 
The analysis presented in this paper explores the main determinants of the use of debt compensation in the banking industry. The dependent variable is CEO inside-debt compensation, measured using two alternative proxies: the debt-based compensation relative to equity-based compensation which represents the CEOs' personal inside debt-to-equity ratio (CEO-debt-to-equity), and the bank CEOs' relative incentive ratio, which is measured as debt-based compensation relative to equity-based compensation scaled by the bank's debt-to-equity ratio (CEO-bankdebt-to-equity).

Table 1

Determinants of inside debt compensation



\begin{tabular}{|c|c|c|c|c|}
\hline Leverage & $\begin{array}{l}0.8525^{* *} \\
(0.040)\end{array}$ & $\begin{array}{c}0.8601 \quad * * * \\
(0.000)\end{array}$ & $\begin{array}{l}1.3800^{* *} \\
(0.021)\end{array}$ & $\begin{array}{l}0.4099^{*} \\
(0.087)\end{array}$ \\
\hline CEO's Age & $\begin{array}{l}0.9479 * * \\
(0.041)\end{array}$ & $\begin{array}{l}0.4094 * * \\
(0.079)\end{array}$ & $\begin{array}{r}0.6072 \\
(0.126)\end{array}$ & $\begin{array}{r}-0.1324 \\
(0.372)\end{array}$ \\
\hline Tenure & $\begin{array}{l}0.0571 \\
(0.666)\end{array}$ & $\begin{array}{r}0.0596 \\
(0.371)\end{array}$ & $\begin{array}{l}0.0527 \\
(0.693)\end{array}$ & $\begin{array}{r}-0.0755 \\
(0.1560)\end{array}$ \\
\hline Growth opportunities & $\begin{array}{r}-0.1129 \\
(0.534)\end{array}$ & $\begin{array}{l}-0.0671 \\
(0.138)\end{array}$ & $\begin{array}{l}0.0564 \\
(0.794)\end{array}$ & $\begin{array}{l}0.1097 \\
(0.153)\end{array}$ \\
\hline Salary & $\begin{array}{l}-0.2073^{* *} \\
(0.022)\end{array}$ & $\begin{array}{l}-0.0366 \\
(0.359)\end{array}$ & $\begin{array}{l}-0.2667 * \\
(0.067)\end{array}$ & $\begin{array}{l}0.0039 \\
(0.946)\end{array}$ \\
\hline Cash bonuses & $\begin{array}{l}-0.0143 * * \\
(0.073)\end{array}$ & $\begin{array}{l}-0.1017 \\
(0.266)\end{array}$ & $\begin{array}{r}-0.0110 \\
(0.142)\end{array}$ & $\begin{array}{l}-0.0026 \\
(0.364)\end{array}$ \\
\hline Size & $\begin{array}{l}0.7578^{*} \\
(0.093)\end{array}$ & $\begin{array}{l}0.5199 * * \\
(0.023)\end{array}$ & $\begin{array}{l}0.3654 \\
(0.401)\end{array}$ & $\begin{array}{l}0.5058^{* *} \\
(0.019)\end{array}$ \\
\hline Year dummy & Yes & Yes & & \\
\hline No. Observations & 130 & 130 & 130 & 130 \\
\hline Adjusted- $\mathrm{R}^{2} /$ pseudo- $\mathrm{R}^{2}$ & 0.363 & 0.445 & 0.221 & 0.201 \\
\hline
\end{tabular}

The dependent variable is inside debt compensation. Columns 1 and 3 report the results using the natural logarithm of CEO-debt-to-equity ratio. Column 2 and 4 report the results using the natural logarithm of the CEO-bankdebt-to-equity ratio. The p-values are reported in parentheses. The asterisks $* * *, * *, *$ show statistical significance at the $1 \%, 5 \%$ and $10 \%$ levels, respectively.

Table (1) presents the results of the regression analysis, to investigate the association between explanatory variables and the two different dependent variables of the first model. Column (1) of Table 1 shows the results of the first model using (CEO-debt-toequity), while Column (2) shows the results of the first model using (CEO-bankdebt-to-equity). The results show that leverage is significantly positively correlated with inside debt compensation. This indicates that banks with high leverage tend to use more debt-like compensation for their executives, in order to reduce risk-shifting problems. CEOs' age is positively and significantly associated with debt-like compensation. This provides insight that older CEOs tend to prefer debt-like compensation as they approach retirement age. This is consistent with prior empirical work which finds that CEOs become more risk-averse with age (Bennett et al., 2012). The results in Column (1) also show that human capital is an important determinant of inside debt compensation. Salary and cash bonuses are negatively related to debt-like compensation. This negative relationship may be due to the fact that cash compensation is negatively associated with inside debt compensation, because this component of compensation exposes the CEO to default risk just as if the manager held a piece of the firm's risky unsecured debt (Liu et al., 2014). The results in Column (1) also show no evidence of an association between CEO inside-debt compensation and CEOs' tenure, investment opportunities, and bank size.

Column (2) of Table (1) presents the results of the second proxy on inside-debt compensation (CEO-bankdebt-to-equity). The results are consistent with the previous measure (CEO-debt-to-equity). Bank leverage is positive (0.860) and statistically significant at $1 \%$. CEO age is also positive and significant at the $10 \%$ level. However, the coefficients of CEO salary and cash bonuses are negative and consistent with the prediction, but not statistically significant. Using (CEO-bankdebt-to-equity) as a measure of inside debt compensation shows that the coefficient of bank size is positive and statistically significant. This indicates that larger banks tend to provide managers with a higher level of inside debt compensation (Cen, 2010; Liu et al., 2014).

A fixed effects model is also employed to examine the determination of CEOs' inside debt compensation. Column (3) and Column (4) in Table (1) show the results of the fixed effects model. Leverage is positively and significantly correlated with (CEO-debt-to-equity) and (CEO-bankdebt-to-equity), with coefficients of 1.379973 and 0.4098925 , respectively. CEO's salary 
in Column (3) also shows a significant negative coefficient at the $10 \%$ level. As expected, inside debt compensation is associated positively with bank size, and the coefficient in Column (4) is 0.5058 at the $5 \%$ level.

\section{Inside debt compensation and bank performance}

Table 2 reports regressions of inside debt compensation on bank performance and a common set of control variables, which follow those used in prior empirical research (e.g. Guo et al., 2006; Wu and Lin, 2019). The dependent variable is bank performance which is measured using ROA and ROE. Inside debt incentives are measured using (CEO-debt-to-equity) and (CEO-bankdebt-to-equity). The model is as follows:

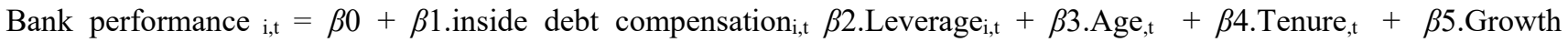
opportunities, $\mathrm{t}+\beta 6$ Salary $_{\mathrm{i}, \mathrm{t}}+\beta 7$. bonus $_{\mathrm{i}, \mathrm{t}}+\beta 8$.Size $_{\mathrm{i}, \mathrm{t}}+\mu_{\mathrm{t}}+\dot{\varepsilon}_{\mathrm{i}, \mathrm{t}}$

Table 2 shows the regression results when the dependent variable is firm performance measured by ROA, and the explanatory variable is debt-like compensation. Column (1) shows the results when bank CEOs' personal inside debt-to-equity ratio is used as a proxy for inside debt incentives (CEO-debt-to-equity). Column (2) shows the results when bank CEOs' relative incentive ratio is used as alternative proxy for bank CEOs' debt compensations (CEO-bankdebt-to-equity).

Table 2

Inside debt compensation and bank performance

\begin{tabular}{|c|c|c|c|c|}
\hline & $(1)$ & $(2)$ & (3) & (4) \\
\hline & $\underline{\text { OLS }}$ & $\underline{\text { OLS }}$ & Fixed effect & Fixed effect \\
\hline & CEO-debt-to-equity & CEO-bankdebt-to-equity & CEO-debt-to-equity & CEO-bankdebt-to-equity \\
\hline \multicolumn{5}{|l|}{ Independent variables } \\
\hline CEO-debt-to-equity & $\begin{array}{c}-0.0003^{*} \\
(0.084)\end{array}$ & & $\begin{array}{c}-0.1514 * \\
(0.089)\end{array}$ & \\
\hline CEO-bankdebt-to-equity & & $\begin{array}{l}-0.0140 * * \\
(0.046)\end{array}$ & & $\begin{array}{l}-0.0144 * * \\
(0.046)\end{array}$ \\
\hline Leverage & $\begin{array}{l}-0.6718 * * * \\
(0.000)\end{array}$ & $\begin{array}{l}-0.6905 * * * \\
(0.000)\end{array}$ & $\begin{array}{r}-0.2666 \\
(0.680)\end{array}$ & $\begin{array}{l}-0.9476 * * * \\
(0.001)\end{array}$ \\
\hline CEO's Age & $\begin{array}{l}0.5686^{* * * *} \\
(0.002)\end{array}$ & $\begin{array}{l}0.5910 * * * \\
(0.002)\end{array}$ & $\begin{array}{l}1.4911 * * * \\
(0.001)\end{array}$ & $\begin{array}{l}0.7538 * * * \\
(0.000)\end{array}$ \\
\hline Tenure & $\begin{array}{r}0.0898 \\
(0.089)\end{array}$ & $\begin{array}{l}0.0881 * \\
(0.093)\end{array}$ & $\begin{array}{r}0.0127 \\
(0.929)\end{array}$ & $\begin{array}{r}0.0836 \\
(0.170)\end{array}$ \\
\hline Growth opportunities & $\begin{array}{l}0.3691 * * * \\
(0.000)\end{array}$ & $\begin{array}{l}0.3510 * * * \\
(0.000)\end{array}$ & $\begin{array}{l}1.1083 * * * \\
(0.000)\end{array}$ & $\begin{array}{l}0.2038 * * \\
(0.040)\end{array}$ \\
\hline Salary & $\begin{array}{r}-0.0173 \\
(0.626)\end{array}$ & $\begin{array}{r}-0.0300 \\
(0.403)\end{array}$ & $\begin{array}{r}-0.1337 \\
(0.396)\end{array}$ & $\begin{array}{l}-0.1558 * * \\
(0.019)\end{array}$ \\
\hline Cash bonuses & $\begin{array}{r}-0.0022 \\
(0.487)\end{array}$ & $\begin{array}{r}-0.0019 \\
(0.540)\end{array}$ & $\begin{array}{l}0.0208 * * \\
(0.011)\end{array}$ & $\begin{array}{l}0.0057^{*} \\
(0.093)\end{array}$ \\
\hline Size & $\begin{array}{l}0.6702 * * * \\
(0.000)\end{array}$ & $\begin{array}{l}0.6721 * * * \\
(0.000)\end{array}$ & $\begin{array}{r}0.1107 \\
(0.830)\end{array}$ & $\begin{array}{l}0.5572 * * \\
(0.044)\end{array}$ \\
\hline Year dummy & Yes & Yes & & \\
\hline No. Observations & 130 & 130 & 130 & 130 \\
\hline Adjusted-R ${ }^{2} /$ pseudo- $\mathrm{R}^{2}$ & 0.327 & 0.331 & 0.325 & 0.342 \\
\hline
\end{tabular}

The dependent variable is bank performance measured using the natural logarithm ROA. Columns 1 and 3 report the results using the natural logarithm of CEO-debt-to-equity ratio. Column 2 and 4 report the results using the natural logarithm of the CEO-bankdebt-to-equity ratio. The p-values are reported in parentheses. The asterisks $* * *, * *, *$ show statistical significance at the $1 \%, 5 \%$ and $10 \%$ levels, respectively.

Consistent with performance hypothesis, the coefficient of the relationship between ROA and inside debt compensation proxies is negative and significant in both regressions (i.e. CEO-debt-to-equity and CEO-bankdebt-to-equity). Better CEO alignment with debt-holders' interests did not result in better bank performance. The use of higher levels of debt-like compensation reduces risk-taking incentives, which results in worse performance. This form of compensation provides executives with fixed claims, like conventional debt, which depend on the firm's solvency for full payment (Tung and Wang, 2011). With regard to the control variables in Table (2), Column (1) and Column (2) show negative and significant association between leverage and the performance measure (ROA) at the $1 \%$ level. Age of the CEO is positively and significantly associated with bank performance at the $5 \%$ level. Tenure is also positive and significant at the $10 \%$ level. The variable of growth opportunities shows a positive and significant correlation to bank performance at the $1 \%$ level. Significant and positive coefficients of size in Column (1) and 
in Column (2) are reported: 0.67024 and 0.67214, respectively. Salary and cash compensation in Column (1) and Column (2) show no significant association with a bank's performance.

Columns (3) and (4) in Table (2) provide empirical results of fixed effects regression, which support the results of OLS regression. Bank CEOs' personal inside debt-to-equity ratio (CEO-debt-to-equity) and bank CEOs' debt compensations (CEObankdebt-to-equity) are related significantly and negatively to bank performance (ROA) at the $10 \%$ and $5 \%$ levels, respectively, suggesting that a higher level of inside debt compensation results in diminished bank performance. This negative association is significant as a proxy for inside debt incentives (CEO-debt-to-equity). Column (2) show the results when bank CEOs' relative incentive ratio is used as an alternative proxy for bank CEOs' debt compensations (CEO-bankdebt-to-equity).

The signs on the control variables in Column (3) and (4) are consistent with the OLS regression results. The coefficient of leverage is negative and significant at the 1\% level in Column (3). CEO age is positive and significant at the $1 \%$ level. Growth opportunities variable is also both positive and significant. Salary is negative and significant at 5\% level in Column (4). However, cash bonuses are positive and significant in Columns (3) and (4) at the 5\% and 10\% levels, respectively. Bank size is also positive and significant at the 5\% level in Column (4).

\section{Robustness tests}

Finally, another proxy of performance is used to conduct additional tests in order to evaluate the robustness of the results on the relationship between inside debt compensation and bank performance. The results of these robustness tests are displayed in Table (6). Specifically, ROE is used to capture the relative incentives created by inside debt compensation and bank performance. Using both proxies, (CEO-debt-to-equity) and (CEO-bankdebt-to-equity), the results support previous outcomes when using ROA to measure bank performance.

Table 3

Inside debt compensation and bank performance

\begin{tabular}{|c|c|c|c|c|}
\hline & (1) & (2) & (3) & (4) \\
\hline & $\frac{\text { OLS }}{\text { CFO-deht-to-equity }}$ & $\frac{\text { OLS }}{\text { CFO-bankdeht-to-equity }}$ & Fixed effect & Fixed effect \\
\hline \multicolumn{5}{|l|}{ Independent variables } \\
\hline CEO-debt-to-equity & $\begin{array}{l}-0.0545^{* *} \\
(0.016)\end{array}$ & & $\begin{array}{l}-0.1257^{*} \\
(0.071)\end{array}$ & \\
\hline CEO-bankdebt-to-equity & & $\begin{array}{l}-0.0271^{*} \\
(0.083)\end{array}$ & & $\begin{array}{c}-1.2079 * \\
(0.071)\end{array}$ \\
\hline Leverage & $\begin{array}{l}0.0591 \\
(0.596)\end{array}$ & $\begin{array}{c}-0.0786^{*} \\
(0.065)\end{array}$ & $\begin{array}{r}0.5112 \\
(0.303)\end{array}$ & $\begin{array}{r}1.2966 \\
(0.498)\end{array}$ \\
\hline CEO's Age & $\begin{array}{r}0.0079 \\
(0.950)\end{array}$ & $\begin{array}{l}-0.1071^{* *} \\
(0.020)\end{array}$ & $\begin{array}{l}0.1220 \\
(0.705)\end{array}$ & $\begin{array}{r}-0.9387 \\
(0.427)\end{array}$ \\
\hline Tenure & $\begin{array}{l}0.0231 \\
(0.518)\end{array}$ & $\begin{array}{l}0.0071 \\
(0.605)\end{array}$ & $\begin{array}{l}0.0393 \\
(0.740)\end{array}$ & $\begin{array}{l}0.6035 \\
(0.156)\end{array}$ \\
\hline Growth opportunities & $\begin{array}{l}0.2620 * * * \\
(0.000)\end{array}$ & $\begin{array}{l}0.2442^{* * *} \\
(0.000)\end{array}$ & $\begin{array}{l}0.1460 \\
(0.372)\end{array}$ & $\begin{array}{r}0.4487 \\
(0.464)\end{array}$ \\
\hline Salary & $\begin{array}{r}-0.0177 \\
(0.466)\end{array}$ & $\begin{array}{r}-0.0006 \\
(0.951)\end{array}$ & $\begin{array}{r}-0.1588 \\
(0.210)\end{array}$ & $\begin{array}{l}0.9354^{* *} \\
(0.040)\end{array}$ \\
\hline Cash bonuses & $\begin{array}{l}0.0035 \\
(0.105)\end{array}$ & $\begin{array}{l}0.0027^{* * *} \\
(0.001)\end{array}$ & $\begin{array}{r}-0.0474 \\
(0.245)\end{array}$ & $\begin{array}{r}-0.0076 \\
(0.741)\end{array}$ \\
\hline Size & $\begin{array}{r}-0.0139 \\
(0.909)\end{array}$ & $\begin{array}{l}0.0689 \\
(0.132)\end{array}$ & $\begin{array}{l}0.6343^{*} \\
(0.060)\end{array}$ & $\begin{array}{r}0.3184 \\
(0.799)\end{array}$ \\
\hline Year dummy & Yes & Yes & & \\
\hline No. Observations & 130 & 130 & 130 & 130 \\
\hline Adjusted- $\mathrm{R}^{2} /$ pseudo- $\mathrm{R}^{2}$ & 0.247 & 0.236 & 0.226 & 0.215 \\
\hline
\end{tabular}

The dependent variable is bank performance measured using the natural logarithm ROE. Columns 1 and 3 report the results using the natural logarithm of CEOdebt-to-equity ratio. Column 2 and 4 report the results using the natural logarithm of the CEO-bankdebt-to-equity ratio. The p-values are reported in parentheses. The asterisks $* * *, * *, *$ show statistical significance at the $1 \%, 5 \%$ and $10 \%$ levels, respectively.

Table (3) reports the results of the OLS and fixed effects regressions. The coefficients on (CEO-debt-to-equity) and (CEObankdebt-to-equity) in Columns (1) and (2) are both negative (-0.05450 and -0.02712 , respectively) and significant (at the 5\% and $10 \%$ levels, respectively). This is consistent with the findings of the primary analyses (i.e. using ROA as a proxy for bank performance). Additional analyses of the fixed effects model show that inside debt compensation (using both measures) is negatively and significantly related to bank performance. These results are generally similar to the theoretical prediction 
advanced in Jensen and Meckling (1976) and Edmans and Liu (2011) that risk-averse executives are likely to make less risky choices when they have compensation in the form of debt compensation, in order to protect the value of their debt holdings. This can benefit debt-holders who prefer firms to be more conservative, but at the expense of shareholders. This finding is consistent with prior empirical studies, such as Cassell et al. (2012), who determine that a firm's future stock return volatility has a negative correlation with CEO inside debt holdings. Additionally, their results show an association between inside debt compensation and the conservative nature of a firm.

Table 3 also reports the results of the control variables when ROE is used to measure bank performance. Column (2) shows that leverage and age are both negative and significant, while growth opportunities and cash bonuses are positive and significant. Column (3) shows that size is positive and significant at the $10 \%$ level, while Column (4) shows that salary is positive and significant at the $5 \%$ level.

Overall, the findings reported in this paper are consistent with the view that inside debt is an effective instrument with which to dampen managers' risk-seeking behaviour. Using debt-based compensation can lead to behaviour which positively impacts debt-holders, as more conservative strategies can decrease the probability of default. Particularly, debt-like compensation can play a key role in reducing the agency costs of debt (known as "asset substitution" or "risk-shifting" problems). This is consistent with the theoretical prediction and empirical findings of established literature related to debt-like compensation (e.g. Jensen and Meckling, 1976; Edmans and Liu, 2011; Cassell et al., 2012). The results of applying the fixed effects regression models do not differ from those obtained previously using the base model. They coincide both in terms of the explanatory variables and in their relationship, although some loss of statistical significance is noted.

\section{Conclusions}

This paper aims to investigate the determinants of the use of inside debt compensation, and the impact of this type of CEO compensation on bank performance, using a sample of 130 bank-year observations related to thirty European banks in the period of 2006 to 2011. The incentive effects of debt-based compensation is equally important to the incentive effect of equity-based compensation, because the use of debt-based compensation as a component of CEOs' compensation plans is common, the magnitude of CEO inside debt compensation often represents a significant portion of CEOs' compensation packages and, more importantly, there are limited empirical studies on the effect of inside debt compensation on bank performance (Sundaram \& Yermack, 2007). The results of this study are consistent with the existing theoretical and empirical literature on debt-based compensation. Two alternative proxies are used in this paper for CEOs' inside debt holdings: the CEOs' personal inside debtequity ratio and the bank CEOs' relative incentive ratio. This paper provides evidence that debt-like compensation is an important determinant of debt-based compensation. Banks rely more heavily on debt-based compensation as leverage increases. Older CEOs, who are considered more risk-averse, have a higher level of inside debt compensation. Larger banks are more likely to use more inside debt compensation. The analysis show that as CEOs' human capital increases, debt-based compensation becomes less important, with a negative association being found between CEOs' human capital and this form of compensation. The results show no linear association between growth opportunities, tenure, and inside debt compensation.

This study also presents empirical evidence on the association between inside debt compensation and bank performance. Bank performance is measured using stock returns on assets and stock return on equity. The regression results reveal a negative relationship between debt-based compensation and bank performance. Thus, it can be seen that the results are consistent with the argument that debt-based compensation motivates CEOs to work in the interest of debt-holders, by following more conservative strategies and thereby reducing "risk shifting" problems.

\section{References}

Acrey, J., McCumber, W., \& Nguyen, T. (2011). CEO incentives and bank risk. Journal of Economics and Business, 63, 456471.

Akram, M. A., Hunjra, A. I., Butt, S., and Ijaz, I. (2015). Earnings management and organizational performance: Pakistan VS India. Basic Research Journal of Business Management and Accounts, 4(9), 211-220.

Alhadab, M., \& Al-Own, B. (2019). Earnings management and equity incentives: evidence from the European banking industry. International Journal of Accounting and Information Management, 27(2), 244-261.

Allen, S.G., \& Clark, R.L. (1987). Pensions and Firm Performance. In Human Resources and the Performance of the Firm. edited by M.M. Kleiner, R.N. Block, M. Roomkin and S.W. Salsburg, Industrial Relations Research Association, $195-242$

Anantharaman, D., Fang, V. W., \& Gong, G. (2014). Inside debt and the design of corporate debt contracts. Management Science, 60(5), 1260-1280.

Bai, G., \& Elyasiani, E. (2013). Bank stability and managerial compensation. Journal of Banking and Finance, 37, 799-813.

Bebchuk, L., \& Jackson, R. (2005). Executive pensions. Journal of Corporate Law, 30, 823-855.

Begley, J. (1994). Restrictive covenants included in public debt agreements: an empirical investigation. Working Paper, University of British Columbia. 
Begley, J., \& Feltham, G. A. (1999). An empirical examination of the relation between debt contracts and management incentives. Journal of Accounting and Economics, 27, 229-259.

Bekkum, S. V. (2016). Inside debt and bank risk. Journal of Financial and Quantitative Analysis, 51(2),359-385.

Bennett, R., Guntay, L., \& Unal, H. (2012). Inside debt, bank default risk and performance during the Crisis. FDIC Center for Financial Research, Working Paper No. 2012-3.

Black, F., \& Scholes, M. (1973). The pricing of options and corporate liabilities. Journal of Political Economy, 81, 637-654.

Bolton, P., Mehran, H., \& Shapiro, J. (2015). Executive compensation and risk taking. Review of Finance, 19(6), $2139-2181$.

Buck, T., Bruce, A., Main, B. G. M., \& Udueni, H. (2003). Long term incentive plans, executive Pay and UK company performance. Journal of Management Studies, 40(7), 1709-1727.

Cadman, B., \& Vincent, L. (2014). The role of defined benefit pension plans in executive compensation. European Accounting Review, 24(4), 779-800

Cao, J., Pan, X., \& Tian, G. (2011). Disproportional ownership structure and pay-performance relationship: evidence from China's listed firms. Journal of Corporate Finance, 17, 541-54.

Cardone-Riportella, C., Samaniego-Medina, R., \& Trujillo-Ponce, A. (2010). What drives bank securitisation? The Spanish experience. Journal of Banking and Finance, 34, 2639-2651.

Cassell, C.A., Huang, S.X., Sanchez, J.M., \& Stuart, M.D. (2012). Seeking safety: the relation between CEO inside debt holdings and the riskiness of firm investment and financial policies. Journal of Financial Economics, 103, 588-610.

Cen, W. (2011). The Determinants of CEO Inside Debt and Its Components. SSRN

Chen, C. R., Steiner, T. L., \& Whyte, A. M. (2006). Does stock option-based executive compensation induce risk-taking? An analysis of the banking industry. Journal of Banking and Finance, 30, 915-945.

Cheng, Q, Warfield, T., \& Ye, M. (2011). Equity Incentives and Earnings Management: Evidence from the Banking Industry. Journal of Accounting, Auditing and Finance, 26(2), 317-349.

Choy, H., Lin, J., \& Officer, M. S. (2014). Does freezing a defined benefit pension plan affect firm risk?. Journal of Accounting and Economics, 57(1), 1-21.

Claessens, S., \& van Horen, N. (2015). The impact of the global financial crisis on banking globalization. IMF Economic Review, 63, 868-918.

Coles, J. L., Daniel, N. D., \& Naveen, L. (2006). Managerial incentives and risk-taking. Journal of Financial Economics, 79 (2), 431-468.

Conyon, M. J., \& Murphy, K. J. (2000). The prince and the pauper? CEO pay in the US and UK. The Economic Journal, 110 (467), 640-671.

Core, J., \& Guay, W. (1999). The use of equity grants to manage optimal equity incentive levels. Journal of Accounting and Economics, 28, 151-184.

Core, J., Holthausen, R., \& Larcker, D. (1999). Corporate governance, chief executive officer compensation, and firm performance. Journal of Financial Economics, 51(3), 371-406.

Core, J.E., \& Guay, W. (2002). Estimating the value of employee stock option portfolios and their sensitivities to price and volatility. Journal of Accounting Research, 40(3), 613-630.

Dang, V. (2019). The effects of loan growth on bank performance: Evidence from Vietnam. Management Science Letters, 9(6), 899-910.

Edmans, A. (2006). "Inside debt”. Working paper, MIT Sloan School of Business.

Edmans, A., \& Liu, Q. (2011). Inside debt. Review of Finance, 15, 75-102.

European Insurance and Occupational Pensions Authority (2013). Financial Stability Report", Second Half-Year Report 2013. Technical Report, EIOPA.

Fahlenbrach, R., \& Stulz, R. (2011). Bank CEO Incentives and the credit crisis. Journal of Financial Economics, 99, 11-26.

Frye, M.B. (2004). Equity-based compensation for employees: firm performance and determinants. Journal of Financial Research, 27(1), 31-54.

Galdeano, D., Ahmed, U., Fati, M., Rehan, R., \& Ahmed, A. (2019). Financial performance and corporate social responsibility in the banking sector of Bahrain: Can engagement moderate?. Management Science Letters, 9(10), 1529-1542.

Gao, H. (2010). Optimal compensation contracts when managers can hedge. Journal of Financial Economics, 97, $218-238$.

Gerakos, J. (2008). CEO pensions: Disclosure, managerial power, and optimal contracting. Working paper, University of Chicago.

Gerakos, J. (2010). Chief executive officer and the pay-pension trade off. Journal of Pension Economics and Finance, 9(2), 303-319.

Guay, W. (1999). The sensitivity of CEO wealth to equity risk: An analysis of the magnitude and determinants. Journal of Financial Economics, 53(1), 43-71.

Guo, W. C., Shiah-Hou, S. R., \& Yang, Y. W. (2006). Stock bonus compensation and firm performance in Taiwan. Managerial finance, 32(11), 862-885.

Hagendorff, J., \& Vallascas, F. (2011). CEO pay incentives and risk-taking: Evidence from bank acquisitions. Journal of Corporate Finance, 17, 1078-1095. 
Jagtiani, J., Kaufman, G., \& Lemieux, C. (2002). The effect of credit risk on bank and bank holding company bond yields: Evidence from the post-FDICIA period. Journal of Financial Research, 25(4), 559-575.

Jensen, M., \& Murphy, K.J. (1990). Performance pay and top-management incentives. Journal of Political Economy, 98(2), 225-264.

Jensen, M., \& Meckling, W. (1976). Theory of the firm: managerial behavior, agency costs, and capital structure. Journal of Financial Economics, 3, 305-360.

Kato, T., \& Kubo, K. (2006). CEO compensation and firm performance in Japan: evidence from new panel data on individual CEO pay. Journal of the Japanese and International Economies, 20, 1-19.

Lazear, E. (1979). Why is there mandatory retirement? . Journal of Political Economy, 87, 1261- 1284.

Lazear, E. (1983). Pensions as severance pay. In Financial Aspects of the United States Pension System, University of Chicago Press, Chicago, 57-85.

Liu, Y., Mauer, D.C., \& Zhang, Y. (2014). Firm cash holdings and CEO inside debt. Journal of Banking and Finance, 42, 83100.

Ma, T., Jiang, M., \& Yuan, X. (2020). Pay me later is not always positively associated with bank risk reduction-From the perspective of long-term compensation and black box effect. Sustainability, 12(35), 1-26.

Matsunaga, S. R. (1995). The effects of financial reporting costs on the use of employee stock options. Accounting Review, 70 (1), 1-26.

Mehran, H., (1995). Executive compensation structure, ownership, and firm performance. Journal of Financial Economics, 38, $163-184$.

Milidonis, A., Nishikawa, T., \& Shim, J. (2017). CEO inside debt and risk taking: Evidence from property-liability insurance firms. The Journal of Risk and Insurance, 86(2), 451-477.

Murphy, K. J. (2013). Executive compensation: Where we are, and how we got there. In Handbook of the Economics of Finance, Volume 2A: Corporate Finance, edited by George M. Constantinides, Milton Harris, and Rene M. Stulz, 211-356. Oxford and Amsterdam: Elsevier, North-Holland.

Ongore, V.O., \& Kusa, G.B. (2013). Determinants of financial performance of commercial banks in Kenya. International Journal of Economics and Financial Issues, 3(1), 237-252.

Rogers, D. (2002). Does executive portfolio structure affect risk management? CEO risk-taking incentives and corporate derivatives usage. Journal of Banking and Finance, 26, 271-295.

Sheikh, S. (2020). CEO inside debt and corporate social responsibility. International Journal of Managerial Finance, 16(4), 525-546.

Srivastav, A., Armitage, S., \& Hagendorff, J. (2014). CEO inside debt holdings and risk shifting: Evidence from bank payout policies. Journal of Banking and Finance, 47(10), 41-53.

Sundaram, R., \& Yermack, D. (2007). Pay me later: inside debt and its role in managerial compensation. Journal of Finance, $62,1551-1588$.

Tung, F., \& Wang, X. (2011). Bank CEOs, inside debt compensation, and the financial crisis. Working Paper, Emory University.

Wei, C., \& Yermack, D. (2011). Investor reactions to CEOs' Inside debt incentives. Review of Financial Studies, 24(11), 38133840 .

Wen, W. (2010). Ownership Structure and Banking Performance: New Evidence in China. Unpublished thesis (PhD), Universitat Autonama De Barcelona.

Wu, T.H., \& Lin, M.C. (2019). Relationship of CEO inside debt and corporate social performance: A data envelopment analysis approach. Finance Research Letters, 29, 308-314.

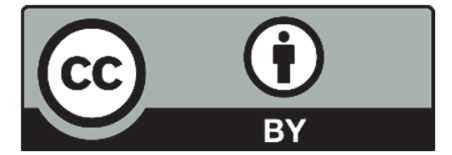

(C) 2020 by the authors; licensee Growing Science, Canada. This is an open access article distributed under the terms and conditions of the Creative Commons Attribution (CC-BY) license (http://creativecommons.org/licenses/by/4.0/). 